\title{
GAMBARAN TINGKAT PENGETAHUAN MASYARAKAT TERHADAP PERTOLONGAN PERTAMA PADA KECELAKAAN LALU LINTAS DI BANJAR BUAGAN, DESA PEMECUTAN KELOD
}

\author{
DESCRIPTION OF THE PUBLIC LEVEL OF \\ KNOWLEDGE OF FIRST AID IN TRAFFIC \\ ACCIDENTS IN BANJAR BUAGAN, PEMECUTAN \\ KELOD
}

I Nyoman Asdiwinata ${ }^{1}$, A.A Istri Dalem Hana Yundari² I Putu Angga Widnyana ${ }^{3}$. STIKes Wira Medika Bali ${ }^{1,2,3}$

\begin{abstract}
ABSTRAK
Kecelakaan lalu lintas dapat mengakibatkan berbagai cedera sampai kematian. Selain faktor korban kecelakaan yang meninggal langsung di tempat kejadian, faktor pertolongan pertama pada korban kecelakaan sangat penting untuk korban kecelakaan untuk mencegah trauma yang lebih berat. Tujuan dari penelitian ini adalah untuk mengetahui gambaran tingkat pengetahuan masyarakat terhadap pertolongan pertama pada kecelakaan lalu lintas di Banjar Buagan, Desa Pemecutan Kelod. Penelitian ini adalah penelitian deskriptif dengan model pendekatan cross sectional. Sampel penelitian ini berjumlah 198 responden dengan menggunakan non probability sampling dengan teknik purposive sampling. Data dikumpulkan dengan lembar kuesioner tingkat pengetahuan masyarakat terhadap pertolongan pertama pada kecelakaan lalu lintas dengan hasil uji validitas $r$ hitung $>0,312$ dan uji reliabilitas $0,931>0,750$. Data yang diperoleh dianalisis dengan program SPSS dengan menggunakan analisis univariat. Hasil penelitian ini menunjukan sebagian besar masyarakat berusia 36-45 tahun, berjenis kelamin laki-laki, berpendidikan SMA/SMK, berpekerjaan swasta. Pengetahuan masyarakat tentang pertolongan pertama pada kecelakaan lalu lintas didapatkan sebagian besar memiliki tingkat pengetahuan cukup yaitu sebanyak 125 responden $(63,1 \%)$. Disarankan bagi tenaga kesehatan memberikan informasi yang adekuat kepada masyarakat tentang cara melakukan pertolongan pertama pada kecelakaan lalu lintas melalui kegiatan penyuluhan.
\end{abstract}

Kata Kunci: Tingkat Pengetahuan, Pertolongan Pertama, Kecelakaan Lalu Lintas

ABSTRACT

Traffic accidents cause various injuries to death. In addition to the accident victims who died directly at the scene, the first aid factor for accident victims is very important for accident victims to prevent more severe trauma. The purpose of this study was describe the 
level of knowledge of the community on first aid in traffic accidents in Banjar Buagan, Pemecutan Kelod. This research was a descriptive study with a cross sectional approach. The sample of this studied was 198 respondents used non probability sampling with purposive sampling technique. Data was collected by questionnaire sheets on the level of community knowledge of first aid in traffic accidents with the results of the validity test $r$ count $>0.312$ and reliability test $0.931>0.750$. The data were analyzed by the SPSS program used univariate analysis. The results of this study show that the majority of people aged 36-45 years old, male sex, high school / vocational education, private employment. The community's knowledge of first aid in traffic accidents was found to have a high level of knowledge, namely 125 respondents (63.1\%). It was recommended for health workers to provide adequate information to the public about how to do first aid in traffic accidents through counseling.

Keywords: Level of Knowledge, First Aid, Traffic Accident.

\begin{tabular}{ll}
\hline $\begin{array}{l}\text { Alamat Korespondensi } \\
\text { Email }\end{array}$ & $\begin{array}{l}\text { STIKes Wira Medika Bali } \\
\text { : widnyanaangga@gmail.com }\end{array}$ \\
\hline
\end{tabular}

\section{PENDAHULUAN}

Kejadian kecelakaan biasanya terjadi sangat cepat dan tiba-tiba sehingga sulit diprediksi kapan dan dimana terjadi. Salah satu kejadian kecelakaan karena kecelakaan lalu lintas. Kecelakaan lalu lintas bukan hanya dapat mengakibatkan berbagai cedera sampai kematian tetapi juga menjadi masalah global yang mempengaruhi sektor kehidupan. Selain faktor korban kecelakaan yang meninggal langsung di tempat kejadian, faktor lain yang juga dapat menyebabkan korban kecelakaan meninggal dunia adalah faktor pertolongan pertama pada korban kecelakaan terutama pada korban yang mengalami trauma, dimana hal ini sangat penting untuk korban kecelakaan (Kurniawan, 2014).

Global Status Report on Road Safety (WHO, 2015), menyatakan kecelakaan lalu lintas dinilai menjadi pembunuh terbesar ketiga, di bawah penyakit jantung koroner dan tuberkulosis, sebanyak 67\% korban kecelakaan lalu lintas berada pada usia produktif, yaitu usia 22-50 tahun. Terdapat sekitar 400.000 korban di bawah usia 25 tahun yang meninggal di jalan raya dengan rata-rata angka kematian 1.000 anak-anak dan remaja setiap harinya. Kecelakaan lalu lintas juga menjadi penyebab utama kematian anak-anak di dunia, dengan rentang usia 10-24 tahun. Berdasarkan data Badan Pusat Statistik Republik Indonesia (BPS RI, 2019), menyatakan angka kecelakaan lalu lintas pada tahun 2017 sebanyak 103.228 kejadian dengan korban meninggal 30.568, luka berat 14.395, luka ringan 119.945 korban. Dari data tersebut dapat menegaskan bahwa kecelakaan lalu lintas di dunia maupun Indonesia menjadi salah satu faktor kematian sesorang yang relatif cukup tinggi.

Berdasarkan data Direktorat Lalu Lintas Polda Bali 2018, menyatakan pada semester I terhitung dari bulan Januari - Juni 2018 terdapat 1.096 kasus kecelakaan lalulintas, dengan korban meninggal dunia sebanyak 242 jiwa, luka berat sebanyak 101, sedangkan luka ringan 1.521. Pada semester II terhitung dari bulan Juli - 
Desember 2018 terjadi peningkatan kasus kecelakaan lalu lintas yaitu sebanyak 1.728 kasus, dengan korban meninggal sebanyak 280 jiwa, luka berat 162 , sedangkan luka ringan 2248. Dari sembilan Kabupaten di Bali, daerah dengan urutan pertama terjadi kasus kecelakaan lalu lintas yaitu daerah Denpasar dengan total 537 kasus, korban meninggal dunia sebanyak 123 jiwa, dengan kerugian materiil Rp 1,801,350.000, dengan black spot Jl. Imam Bonjol, Banjar Buagan, Wilayah Desa Pemecutan Kelod.

Menurut Kurniawan (2014), mengungkapkan bahwa kecelakaan lalu lintas merupakan sebagai salah satu faktor kematian yang menimbulkan kondisi yang membahayakan jiwa manusia. Daerah cedera yang meliputi kepala 55,1\% dengan commotion cerebri $6,5 \%$, kaki $12,3 \%$, dan lutut/tungkai bawah 9,4\%. Korban kecelakaan lalu lintas yang mengalami cedera kepala, waktu pertolongan terbaik adalah 4 menit pertama, jika sampai tertunda lebih dari 30 menit maka tingkat keberhasilan pertolongan tinggal $20 \%$ sementara jika mengharapkan pertolongan pertama dilakukan setelah dirumah sakit maka waktu tanggap sering terlambat sehingga membutuhkan pertolongan secara cepat pada lokasi kejadian untuk mencegah morbiditas dan mortalitas korban. Pertolongan yang diberikan di lokasi kejadian merupakan bagian dari pre-hospital care. Pre-hospital care ini diberikan kepada korban sebelum korban kecelakaan lalu lintas sampai di rumah sakit. Pemberian pertolongan pre-hospital care secara tepat dapat menurunkan resiko kematian akibat trauma. Tingginya angka kematian pada korban kecelakaan lalu lintas bisa disebabkan oleh pemberian pertolongan pertama yang kurang tepat pada korban.

Salah satu upaya pemberian pertolongan pre-hospital care dalam melakukan tindakan awal pertolongan pertama pada kecelakaan lalu lintas yaitu melalui Denpasar Mantap Kesehatan Masyarakat (DAMAKESMAS), merupakan program inovasi pelayanan kesehatan masyarakat untuk mendukung program padmaksara dalam mewujudkan playanan prima. Ruang lingkup damakesmas salah satunya Sistem Pelayanan Gawat Darurat Terpadu Sehari-hari (SPGDT-S), kegiatan ini bertujuan untuk meningkatkan akses pelayanan kemasyarakat yang tiba-tiba mengalami kesakitan yang bersifat emergency dan tidak mempunyai kendaraan untuk membawa ke fasilitas kesehatan. Denpasar mantap dalam pelayanan pra rumah sakit dan rujukan. Sebelumnya pelayanan pra rumah sakit (Prehospital medical services system) di Kota Denpasar dilayani oleh 2 Public Safety Center (PSC) dengan tenaga masyarakat umum yang terlatih sehingga hanya mampu merujuk saja agar PSC juga mampu menangani dan mentriage langsung di TKP maka dilengkapi dengan tenaga medis (kontrak) yang direkrut oleh dinas kesehatan. Oleh karena permintaan masyarakat akan pelayanan pra rumah sakit dan rujukan terus meningkat maka di mantapkan dalam program damakesmas dengan mengikutkan tiga puskesmas rawat inap 24 jam. Sehingga sekarang ada 5 tim yang tersebar di keempat Kecamatan yaitu PSC Juanda Renon, PSC Merpati Denpasar Barat, Puskesmas 1 Denpasar Timur, Puskesmas 4 Denpasar Selatan dan Puskesmas Pembantu Dauh Puri Pekambingan. (KEMENKES RI, 2018).

Teknis pelaksanaan alur SPGDT-S yaitu Masyarakat dengan kondisi gawat darurat menelpon ke 119-112/223333, Petugas call center yaitu Pusat Pengendalian 
Oprasi Penanggulangan Bencana (PUSDALOP) menerima telepon dan men "TRIAGE" identitas, alamat dan kondisi pasien, Petugas call center menghubungi puskesmas atau PSC sesuai dengan lokasi dilihat dari layar TV mempergunakan GPS, Puskesmas/PSC yang mendapa panggilan segera meluncur ke TKP dengan mempergunakan Tab dan bantuan GPS, Pergerakan dari tim bisa dimonitor dari layar TV yang ada di PUSDALOP dan puskesmas, Masyarakat/pasien mendapatkan pertolongan/pelayanan segara, Jika bukan termasuk pasien emergency yang memerlukan tindakan rujukan ke rumah sakit maka akan ditanggani langsung dirumah pasien atau observasi di puskesmas 24 jam, Petugas memastikan jaminan kesehatan yang akan digunakan oleh pasien, Pasien JKN yang memerlukan rujukan akan dirujuk ke rumah sakit yang bekerjasama dengan BPJS, sedangkan pasien yang tidak memiliki jaminan bisa dirujuk ke rumah sakit terdekat. (KEMENKES RI, 2018).

Pertolongan pertama sangat penting perannya jika berada dalam keadaan yang tidak diharapkan seperti kecelakaan. Masyarakat sudah banyak yang mengetahui pentingnya pertolongan pertama namun tidak sampai pada tahap mempelajari. Selain itu masyarakat beranggapan bahwa pertolongan pertama berguna ketika situasi gawat darurat yang mungkin tidak akan mereka alami. Perlu dipahami bahwa pertolongan pertama yang diberikan ketika kecelakaan merupakan bantuan yang sangat mendesak dan sangat dibutuhkan. Mendesak karena pada saat itu paramedis tidak langsung mendatangi korban. Meskipun demikian, tanpa didasari dengan pengetahuan yang benar tentang pertolongan pertama, masyarakat seringkali menjadi panik dan tidak tahu harus berbuat apa ketika menghadapi kondisi darurat tersebut. Sehingga, karena salah penanganan dari awal itulah justru memperparah situasi serta kondisi korban (Cho, 2015).

Masyarakat awam merupakan masyarakat pertama yang mengetahui kejadian kecelakaan sebelum ditangani oleh tenaga medis di rumah sakit. Masyarakat yang paham tentang penanganan korban kecelakaan akan mampu menolong nyawa korban sebelum ditangani tenaga medis, sedangkan masyarakat yang memiliki pengetahuan kurang dalam penanganan korban kecelakaan akan tidak bisa menangani korban tersebut sebelum ditangani pihak medis, padahal pertolongan pertama perlu dilakukan untuk menyelamati nyawa korban kecelakaan lalu lintas (Khoirul, 2013).

Menurut Anwar (2014), mengungkapkan tindakan pertolongan pertama merupakan sebuah perlakuan pada korban kecelakaan sebelum ditangani oleh petugas medis dengan tujuan menghindarkan korban dari cedera yang lebih parah. Tujuan dilakukannya tindakan atau penanganan awal kondisi gawat darurat pada kecelakaan lalu lintas untuk menyelamatkan kehidupan, mencegah keadaan menjadi lebih buruk dan mempercepat kesembuhan pada korban. Upaya pertolongan terhadap korban kecelakaan lalu lintas harus dipandang sebagai satu sistem yang terpadu dan tidak terpecah-pecah, mulai dari pre-hospital stage, hospital stage dan rehabilitation stage, sehingga mampu mengurangi resiko kematian dan kecacatan fisik. Masyarakat awam yang melakukan penanganan pertama pada korban gawat darurat harus menguasai tiga cara dasar dalam keadaan darurat seperti meminta bantuan pertolongan, menguasai teknik bantuan hidup dasar (resusitasi jantung paru) dan menguasai teknik menghentikan perdarahan. 
Berdasarkan hasil penelitian yang dilakukan oleh Kurniawan (2014), menyatakan bahwa sebesar 55\% masyarakat di Tegal masih memiliki pengetahuan kurang terhadap penanganan kondisi gawat darurat, sebanyak 25\% masyarakat memiliki pengetahuan yang cukup, dan sebanyak 20\% masyarakat memiliki pengetahuan yang baik terhadap penanganan kondisi gawat darurat pada korban kecelakaan lalu lintas. Beberapa faktor yang menyebabkan pengetahuan masyarakat kurang dalam penanganan kondisi gawat darurat pada korban kecelakaan lalu lintas yaitu kesadaran pengetahuan dan keberanian dalam melakukan tindakan pertolongan pertama pada kecelakaan lalu lintas serta masih rendahnya tindakan stakeholders pemerintah kota, petugas kepolisian, dan tenaga kesehatan dalam memberikan tindakan penyuluhan dan praktek pada masyarakat dalam mengenai kondisi gawat darurat.

Berdasarkan hasil studi pendahuluan yang dilakukan pada tanggal 21 Januari 2019 di Banjar Buagan, Wilayah Desa Pemecutan Kelod, melakukan wawancara dengan jumlah 10 orang masyarakat diantaranya 4 remaja laki-laki dan 6 orang dewasa di lingkungan Banjar Buagan tentang pertolongan pertama yang dilakukan saat terjadi kecelakaan lalu lintas, didapatkan hasil wawancara bahwa mereka hanya mengangkat korban dari lokasi kejadian kecelakaan ke kendaraan yang melintas untuk diantar kerumah sakit atau puskesmas terdekat. Berdasarkan uraian latar belakang tersebut perlu dilakukan penelitian tentang "gambaran tingkat pengetahuan masyarakat terhadap pertolongan pertama pada kecelakaan lalu lintas di Banjar Buagan, Desa Pemecutan Kelod.”

\section{METODE PENELITIAN}

Penelitian ini bersifat kuantitatif dengan desain penelitian yang digunakan adalah penelitian deskriptif dengan model pendekatan cross sectional. Penelitian ini dilakukan di Banjar Buagan, Desa Pemecutan Kelod pada tanggal 19 Maret 2019 sampai 16 April 2019. Populasi penelitian ini adalah seluruh masyarakat asli yang tinggal di Banjar Buagan, Desa Pemecutan Kelod dengan jumlah 400 masyarakat. Sampling yang digunakan adalah non probability sampling dengan teknik purposive sampling dengan sampel sebanyak 198 masyarakat. Teknik pengumpulan data dengan cara memberikan kuesioner kepada responden. Teknik analisis data yang digunakan pada penelitian ini adalah analisis univariat.

\section{HASIL DAN DISKUSI}

\section{HASIL}

\section{Karakteristik subyek penelitian}

Adapun karakteristik responden yang diperoleh berdasarkan umur, jenis kelamin, pendidikan, dan pekerjaan di distribusikan ke dalam table sebagai berikut: 1. Karakteristik Responden Berdasarkan Umur 
Tabel 1

Gambaran Karakteristik Responden Berdasarkan Umur di Banjar Buagan, Desa Pemecutan Kelod Tahun 2019

\begin{tabular}{ccc}
\hline Umur & Frekuensi & Persentase (\%) \\
\hline $17-25$ & 50 & 25,3 \\
\hline $26-35$ & 43 & 21,7 \\
\hline $36-45$ & 67 & 33,8 \\
\hline $46-55$ & 38 & 19,2 \\
\hline Total & $\mathbf{1 9 8}$ & $\mathbf{1 0 0}$ \\
\hline
\end{tabular}

Berdasarkan tabel 1 menunjukan bahwa dari keseluruhan responden sebagian besar responden berada pada umur 36-45 tahun yaitu sebanyak 67 responden $(33,8 \%)$, dan sebagian kecil responden berada pada umur 46-55 tahun yaitu sebanyak 38 responden (19,2\%).

2. Gambaran Karakteristik Responden Berdasarkan Jenis Kelamin

Tabel 2

Gambaran Karakteristik Responden Berdasarkan Jenis Kelamin di Banjar Buagan, Desa Pemecutan Kelod Tahun 2019

\begin{tabular}{ccc}
\hline Jenis Kelamin & Frekuensi & Persentase (\%) \\
\hline Laki-laki & 121 & 61,1 \\
\hline Perempuan & 77 & 38,9 \\
\hline Total & $\mathbf{1 9 8}$ & $\mathbf{1 0 0}$ \\
\hline
\end{tabular}

Berdasarkan tabel 2 menunjukan bahwa dari keseluruhan responden sebagaian besar responden laki-laki yaitu sebanyak 121 responden $(61,1 \%)$, dan sebagian kecil responden perempuan yaitu sebanyak 77 responden $(38,9 \%)$.

3. Gambaran Karakteristik Responden Berdasarkan Pendidikan

\section{Tabel 3}

Gambaran Karakteristik Responden Berdasarkan Pendidikan di Banjar Buagan, Desa Pemecutan Kelod Tahun 2019

\begin{tabular}{ccc}
\hline Pendidikan & Frekuensi & Persentase (\%) \\
\hline Tidak Sekolah & 0 & 0 \\
\hline SD & 10 & 5,1 \\
\hline SMP & 27 & 13,6 \\
\hline SMA/SMK & 133 & 67,2 \\
\hline Perguruan Tinggi & 28 & 14,1 \\
\hline Total & $\mathbf{1 9 8}$ & $\mathbf{1 0 0}$
\end{tabular}

Berdasarkan tabel 3 menunjukan bahwa dari keseluruhan responden sebagian besar responden memiliki pendidikan SMA/SMK yaitu sebanyak 133 responden $(67,2 \%)$, dan sebagian kecil responden memiliki pendidikan SD yaitu sebanyak 10 responden $(5,1 \%)$. 
4. Karakteristik Responden Berdasarkan Pekerjaan

Tabel 4

Gambaran Karakteristik Responden Berdasarkan Pekerjaan di Banjar Buagan,

Desa Pemecutan Kelod Tahun 2019

\begin{tabular}{ccc}
\hline Pekerjaan & Frekuensi & Persentase (\%) \\
\hline Tidak Bekerja & 53 & 26,8 \\
\hline PNS, TNI, POLISI & 6 & 3,0 \\
\hline Swasta & 112 & 56,6 \\
\hline Wiraswasta & 27 & 13,6 \\
\hline Petani & 0 & 0 \\
\hline Total & $\mathbf{1 9 8}$ & $\mathbf{1 0 0}$
\end{tabular}

Berdasarkan tabel 4 menunjukan bahwa dari keseluruhan responden sebagian besar responden memiliki pekerjaan swasta yaitu sebanyak 112 responden $(56,6 \%)$, dan sebagian kecil responden memiliki pekerjaan PNS, TNI, POLISI yaitu sebanyak 6 responden $(3,0 \%)$.

Hasil pengamatan terhadap objek peneliti berdasarkan variabel penelitian

1. Karakteristik Responden Berdasarkan Tingkat Pengetahuan Masyarakat Terhadap Pertolongan Pertama Pada Kecelakaan Lalu Lintas

Tabel 5

Gambaran Karakteristik Responden Berdasarkan Tingkat Pengetahuan Masyarakat Terhadap Pertolongan Pertama Pada Kecelakaan Lalu Lintas di Banjar Buagan, Desa Pemecutan Kelod Tahun 2019

\begin{tabular}{ccc}
\hline Kategori & Frekuensi & Persentase (\%) \\
\hline Baik & 49 & 24,7 \\
\hline Cukup & 125 & 63,1 \\
\hline Kurang & 24 & 12,1 \\
\hline Total & $\mathbf{1 9 8}$ & $\mathbf{1 0 0}$ \\
\hline
\end{tabular}

Berdasarkan Tabel 5 menunjukan bahwa dari keseluruhan responden sebagian besar responden memiliki tingkat pengetahuan cukup yaitu 125 responden $(63,1 \%)$, dan sebagian kecil responden memiliki tingkat pengetahuan kurang yaitu 24 responden $(12,1 \%)$.

\section{DISKUSI}

Karakteristik Masyarakat Dengan Pertolongan Pertama Kecelakaan Lalu Lintas

1. Karakteristik responden yang dikumpulkan pada penelitian ini mencakup umur, jenis kelamin, pendidikan, dan pekerjaan. Ditemukan hasil pengamatan peneliti terkait karakteristik umur responden sebagian besar ada pada rentang umur 3645 tahun yang mana kategori umur tersebut masuk dalam kategori dewasa akhir menurut Depkes RI (2009). Hasil penelitian ini sejalan dengan penelitian Widyastuti (2017), yang meneliti tentang Gambaran Pengetahuan Masyarakat 
Pesisir Tentang Pertolongan Korban Tenggelam di Kenjeran Surabaya. Penelitian tersebut menunjukan bahwa masyarakat sebagian besar berada pada usia 36-45 tahun yaitu sebanyak 16 responden (45,7\%). Menurut peneliti umur berkontribusi terhadap pengetahuan masyarakat dalam melaksanakan suatu tindakan karena pada masa usia dewasa akhir sudah memiliki banyak pengalaman, semakin bertambahnya umur seseorang semakin banyak informasi yang didapat, dan semakin banyak hal yang dikerjakan sehingga semakin tinggi proses kematangan berfikirnya. Umur menurut Niven (2012) adalah usia yang terhitung mulai dari saat dilahirkan sampai saat akan berulang tahun. Semakin cukup umur tingkat kematangan dan kekuatan seseorang akan lebih matang dalam berfikir dan bekerja. Dari segi kepercayaan, masyarakat yang lebih dewasa akan lebih dipercaya dari pada orang yang belum cukup tinggi tingkat kedewasaannya. Semakin dewasa seseorang, maka cara berfikir semakin matang dan teratur melakukan suatu tindakan. Menurut Muhsin (2017) seorang dengan usia dewasa memiliki sikap dalam perkembangannya adalah belajar untuk saling ketergantungan, tanggung jawab terhadap orang lain. Hal tersebut disebabkan kematangan proses berfikir seseorang dipengaruhi oleh pemikirannya dimana umur seseorang yang bertambah akan semakin tinggi proses kematangan berfikirnya.

2. Jenis kelamin laki-laki mendominasi karakteristik responden pada keseluruhan penelitian ini yaitu sebanyak 121 responden $(61,1 \%)$. Hasil penelitian ini sejalan dengan Prasetyo (2017), yang meneliti tentang Identifikasi Tingkat Pengetahuan Masyarakat Pesisir Tentang Pertolongan Pertama Pada Kejadian Tenggelam di Desa Batu Gong Kabupaten Konawe Provinsi Sulawesi Tenggara. Hasil penelitian tersebut mendapatkan sebagian besar responden yang berjenis kelamin laki-laki, yaitu sebanyak 32 responden (68,09\%). Menurut peneliti jenis kelamin berkontribusi terhadap pengetahuan masyarakat, karena jenis kelamin tidak ada batas ideal perbandingan antara masyarakat laki-laki dan perempuan, namun masyarakat laki-laki umumnya dibutuhkan saat melakukan pertolongan pada kecelakaan lalu lintas dimana dalam hal tersebut dibutuhkan untuk mengamankan lingkungan agar tetap kondusif dan dalam hal penangana korban untuk membantu memindahkan beban yang berat seperti korban kecelakaan yang memiliki badan yang gemuk serta tindakan yang lain yang sulit dilakukan oleh perempuan dimana akan menggangu kelancaran proses dalam penyelamatan korban kecelakaan. Menurut Irwing (2009) setiap laki-laki maupun perempuan memiliki tingkat pengetahuan yang sama karena akses untuk menerima ilmu pengetahuan atau pendidikan tidak hanya prioritas pada laki-laki melainkan memiliki prioritas yang sama baik perempuan maupun laki-laki dengan demikian apabila informasi dan pengetahuan yang didapatkan baik maka tingkat pengetahuan perempuan maupun laki-laki akan relative sama.

3. Berdasarkan tingkat pendidikan didapatkan sebagian besar responden memiliki tingkat pendidikan SMA/SMK yaitu 133 responden (67,2\%). Hasil penelitian ini sejalan dengan penelitian Suyami (2012), yang meneliti tentang Tingkat Pengetahuan Masyarakat Tentang Pertolongan Pertama pada Luka Bakar. Hasil penelitian tersebut mendapatkan sebagian besar responden yang berpendidikan SMA, yaitu 46 responden $(64,8 \%)$. Menurut peneliti pendidikan berkontribusi 
terhadap pengetahuan masyarakat dalam menjalankan suatu tindakan karena, jenjang pendidikan yang tinggi umumnya akan memiliki pengetahuan dan wawasan yang luas sehingga memiliki keterampilan dan kemampuan yang baik dalam melaksanakan tindakan. Pendidikan menurut Niven (2012) adalah usaha sadar dan terencana untuk mewujudkan suasana belajar dan proses pembelajaran agar peserta didik secara aktif mengembangkan prestasi dirinya untuk memiliki kekuatan spiritual keagamaan, pengendalian diri, kepribadian, kecerdasan, akhlak mulia, serta keterampilan yang diperlukan dirinya, masyarakat, bangsa, dan negara. Tingkat pendidikan masyarakat turut menentukan mudah tidaknya seseorang menyerap dan memahami pengetahuan yang mereka peroleh (Wawan, 2010). Pernyataan ini didukung oleh Notoatmodjo (2010) tingkat pendidikan yang diperoleh seseorang dari bangku sekolah dapat mempengaruhi pengetahuan seseorang. Pada umumnya semakin tinggi pendidikan seseorang semakin mudah menerima informasi sehingga banyak pula pengetahuan yang dimiliki dalam bertindak.

4. Pekerjaan dalam penelitian ini menunjukan sebagian besar responden memiliki pekerjaan swasta yaitu 112 responden (56,6\%). Hasil penelitian ini sejalan dengan penelitian Wijaya (2016), yang meneliti tentang Tingkat Pengetahuan Bantuan Hidup Dasar pada Masyarakat di Kecamatan Denpasar Utara. Hasil penelitian tersebut mendapatkan sebagian besar responden yang berpekerjaan swasta, yaitu 202 responden (55,3\%). Menurut peneliti pekerjaan berkontribusi terhadap pengetahuan masyarakat, karena seseorang yang telah bekerja memiliki pengalaman yang luas dan pengalaman yang lebih dibandingkan dengan orang yang tidak bekerja dan seseorang individu akan melakukan sesuatu tindakan berdasarkan pengalamannya. Seseorang yang berpengalaman akan melakukan tindakan sesuai ketentuan yang mereka kenal dan tidak merasa canggung dalam tindakannya. Pekerjaan merupakan suatu usaha untuk dapat menunjang kehidupan individu dan kehidupan keluarganya (Notoatmodjo, 2010). Seorang pekerja memiliki pengalaman informasi dan kemampuan adaptasi yang lebih baik di bandingkan dengan orang yang tidak bekerja. Pengalaman belajar dalam bekerja yang dikembangkan memberikan pengetahuan dan ketrampilan professional serta pengalaman belajar selama bekerja akan dapat mengembangkan kemampuan mengambil keputusan yang merupakan manifestasi dari keterpaduan menalar secara ilmiah dan etik yang bertolak dari masalah nyata (Purwanto, 2010).

\section{Pengetahuan Masyarakat Terhadap Pertolongan Pertama Kecelakaan Lalu Lintas}

Berdasarkan hasil penelitian didapatkan sebagian besar memiliki tingkat pengetahuan cukup sebanyak 125 responden $(63,1 \%)$. Tingkat pengetahuan cukup dalam penelitian ini didapatkan karena sudah dikategorikan berdasarkan nilai hasil akhir dalam penilaian peneliti terhadap responden dimana nilai tersebut kategori pengetahuan baik jika jawaban benar $76 \%-100 \%$, kategori cukup jika jawaban benar 56\%-75\%, dan kategori kurang jika jawaban benar $<56 \%$. Hasil penelitian ini sejalan dengan penelitian Suyami (2012), yang meneliti tentang Tingkat Pengetahuan Masyarakat Tentang Pertolongan Pertama Pada Luka Bakar. Hasil 
penelitian tersebut menunjukan sebagian besar masyarakat mempunyai tingkat pengetahuan yang cukup yaitu sebanyak 34 responden (47,9\%).

Tingkat pengetahuan masyarakat terhadap pertolongan pertama pada kecelakaan lalu lintas dikategorikan "Cukup". Hasil tersebut dapat dilihat berdasarkan kuesioner yang sudah dijawab oleh sebagian besar responden yang berisi 15 item pernyataan dengan memiliki topik berupa pengertian, tujuan, prinsip, dan langkah pertolongan pertama pada kecelakaan. Tingkat pengetahuan masyarakat berkaitan dengan topik pengertian pertolongan pertama pada kecelakaan dengan salah satu pernyataannya "Pertolongan pertama pada kecelakaan menggunakan sarana dan prasarana yang ada di rumah sakit". Pernyataan tersebut mendapatkan respon dari sebagian besar responden menjawab dengan kategori "Benar". Tingkat pengetahuan masyarakat berkaitan dengan topik tujuan pertolongan pertama pada kecelakaan dengan salah satu pernyataannya berupa "Tujuan pertolongan pertama pada kecelakaan yaitu membuat cacat yang lebih berat ". Pernyataan tersebut mendapatkan respon dari sebagian besar responden menjawab dengan kategori "Benar". Tingkat pengetahuan masyarakat berkaitan dengan topik prinsip pertolongan pertama pada kecelakaan dengan salah satu pernyataannya berupa "Saat melakukan pertolongan pertama kecelakaan, lakukan perawatan secepat mungkin walau menambah kerusakan”. Pernyataan tersebut mendapatkan respon dari sebagian besar responden menjawab dengan kategori "Benar". Tingkat pengetahuan masyarakat berkaitan dengan topik langkah pertolongan pertama pada kecelakaan dengan salah satu pernyataannya berupa "Jika terjadi perdarahan maka segera menghentikan perdarahan". Pernyataan tersebut mendapatkan respon dari sebagian besar responden menjawab dengan kategori "Salah". Hal tersebut dikarenakan adanya pengaruh beberapa faktor seperti faktor umur, jenis kelamin, pendidikan, dan pekerjaan.

Pendidikan merupakan salah satu faktor yang mempengaruhi tingkat pengetahuan seseorang. Hal tersebut di perkuat berdasarkan hasil penelitian dimana didapatkan sebagian besar masyarakat yang berada di Banjar Buagan, Desa Pemecutan Kelod memiliki tingkat pendidikan SMA/SMK. Menurut Notoatmodjo (2010) mengungkapkan bahwa pendidikan berdampak pada peningkatan wawasan atau pengetahuan seseorang. Hal tersebut membuktikan semkin tinggi tingkat pendidikan seseorang maka semakin baik tingkat pengetahuan orang tersebut. Masyarakat dengan tingkat pendidikan yang tinggi akan mampu menerima dan memahami informasi yang diberikan, serta mampu mengaplikasikan lebih baik dibandingkan dengan masyarakat tingkat pendidikan rendah.

Menurut Mantra (2010) mengungkapkan bahwa semakin tinggi pendidikan seseorang maka semakin mudah orang tersebut untuk menerima informasi. Semakin banyak informasi yang masuk semakin banyak pula pengethuan yang di dapat. Sebaliknya pendidikan yang kurang akan menghambat perkembangan sikap terhadap nilai-nilai yang baru diperkenalkan (Mubarak, 2009). Umur merupakan faktor yang mempengaruhi tingkat pengetahuan seseorang. Hal tersebut di perkuat berdasarkan hasil penelitian dimana di dapatkan sebagian besar masyarakat yang berada di Banjar Buagan, Desa Pemecutan Kelod memiliki umur 36-45 tahun. Notoadmodjo (2010) usia atau umur adalah lama waktu hidup sejak dilahirkan atau diadakan. Usia antara 36-45 tahun mempengaruhi pengetahuan seseorang, semakin 
tua usia seseorang akan lebih mudah orang itu dalam mencerna suatu informasi yang didapat. Umur juga berpengaruh pada psikis seseorang dimana umur muda sering menimbulkan ketegangan, kebingungan, rasa cemas dan rasa takut sehingga dapat berpengaruh terhadap tingkah lakunya.

Hal ini dapat diasumsikan peneliti bahwa pengetahuan masyarakat terhadap pertolongan pertama pada kecelakaan lalu lintas termasuk dalam kategori cukup karena hal tersebut menunjukan sebagian besar masyarakat sudah mulai sadar tentang pentingnya melakukan pertolongan pertama pada kecelakaan lalu lintas akan tetapi masih ada masyarakat yang kurang memahami bagaimana cara melakukan pertolongan pertama pada kecelakaan lalu lintas yang baik dan benar. Hal tersebut dikarenakan kurangnya informasi yang adekuat dari petugas kesehatan Puskesmas tentang pentingnya pertolongan pertama pada kecelakaan lalu lintas sehingga dapat mempengaruhi pengetahuan masyarakat. Pentingnya pemberian informasi dari petugas kesehatan tentang pertolongan pertama pada kecelakaan lalu lintas dapat membuat masyarakat dalam mengetahui dan memahami tentang pertolongan pertama pada kecelakaan lalu lintas yang baik dan benar sehingga masyarakat mampu melakukan pertolongan pertama pada kecelakaan lalu lintas. Kunci kesuksesan pertama dalam mengarahkan pendidikan mengenai pertolongan pertama pada kecelakaan lalu lintas, mencegah terjadinya trauma yang lebih berat. Serta berhasil atau gagalnya pelaksanaan pertolongan pertama pada kecelakaan lalu lintas terletak pada masyarakat itu sendiri dengan cara melakukan pertolongan pertama yang baik dan benar (Caray, 2009).

\section{SIMPULAN DAN SARAN}

\section{Simpulan}

Hasil penelitian gambaran tingkat pengetahuan masyarakat terhadap pertolongan pertama pada kecelakaan lalu lintas di Banjar Buagan, Desa Pemecutan Kelod tahun 2019 dapat di simpulkan, karakteristik tentang pertolongan pertama pada kecelakaan lalu lintas berdasarkan umur sebagaian besar berada pada kelompok umur 36-45 tahun yaitu 67 responden $(33,8 \%)$, berdasarkan jenis kelamin sebagian besar responden berjenis kelamin laki-laki yaitu sebanyak 121 responden $(61,1 \%)$, berdasarkan pendidikan sebagian besar responden memiliki tingkat pendidikan SMA/SMK yaitu sebanyak 133 responden $(67,2 \%)$, dan berdasarkan pekerjaan sebagian besar responden berpekerjaan swasta yaitu sebanyak 112 responden $(56,6 \%)$, tingkat pengetahuan masyarakat terhadap pertolongan pertama pada kecelakaan lalu lintas didapatkan sebagian besar memiliki tingkat pengetahuan cukup yaitu 125 responden $(63,1 \%)$.

\section{Saran}

Berdasarkan hasil penelitian yang di dapatkan, peneliti mengusulkan beberapa saran terkait dalam tingkat pengetahuan masyarakat terhadap pertolongan pertama pada kecelakaan lalu lintas yaitu sebagai berikut:

1. Bagi Pemerintah Kota Denpasar

Kepada pemerintah kota agar melakukan evaluasi dan peningkatan sistem pelayanan di bidang kelengkapan sarana dan prasarana pertolongan pertama 
pada kecelakaan lalu lintas, sehingga dalam memberikan pertolongan pertama pada kecelakaan lalu lintas masyarakat lebih sigap dan cepat.

2. Bagi Petugas Kepolisian Denpasar Barat

Kepada petugas kepolisian lalu lintas agar dapat lebih meningkatkan kualitas profesinya dalam melayani masyarakat dengan berbagai upaya dan tindakan yang dibutuhkan oleh masyarakat yang membutuhkan bantuannya.

\section{Bagi Puskesmas Denpasar Barat I}

Kepada petugas promosi kesehatan agar memberikan penyuluhan tentang pertolongan pertama kecelakaan lalu lintas, karena kategori masyarakat di Banjar Buagan, Desa Pemecutan Kelod tersebut masih cukup. Agar masyarakat mampu melakukan pertolongan pertama pada kecelakaan lalu lintas.

4. Bagi Masyarakat di Banjar Buagan, Desa Pemecutan Kelod Diharapkan masyarakat agar meningkatkan pengetahuan tentang pertolongan pertama pada kecelakaan lalu lintas, dan datang saat diadakan penyuluhan.

5. Bagi istitusi STIKes Wira Medika Bali

Kepada institusi pendidikan agar menambah dan memperkaya refrensi perpustakaan serta dapat memberikan informasi mengenai pertolongan pertama pada kecelakaan lalu lintas maupun pertolongan pertama pada kasus lainya.

6. Bagi Peneliti selanjutnya Kepada peneliti selanjutnya diharapkan melakukan penelitian lebih luas mengenai tingkat pengetahuan masyarakat terhadap pertolongan pertama pada kecelakaan lalu lintas dengan melakukan pengamatan secara langsung atau observasi terhadap pelaksanaan pertolongan pertama kecelakaan lalu lintas yang dilakukan oleh masyarakat serta mempelajari faktor-faktor lain yang bisa mempengaruhi tingkat pengetahuan masyarakat terhadap pertolongan pertama pada kecelakaan lalu lintas.

\section{DAFTAR PUSTAKA}

1. Anwar, K. 2014. Kampanye Pentingnya Mengetahui Pengetahuan Dasar Pertolongan Pertama pada Kecelakaan Lalu Lintas.

2. Badan Pusat Statistik Republik Indonesia. 2019. Jumlah Laka Lantas. Available: www.bps.go.id.

3. Cho. 2015. Hand Book P3K: Pertolongan Pertama pada Kecelakaan. Yogyakarta: Pustaka Cerdas.

4. Departemen Kesehatan Republik Indonesia. 2009. Kategori Umur. Available: www.depkes.go.id.

5. Direktorat Lalu Lintas Polda Bali. 2018. Jumlah Laka Lantas. Bali.

6. Kementrian Kesehatan Republik Indonesia. 2018. Damakesmas, Denpasar Mantap Kesehatan Masyarakat. Available: www.yankes.depkes.go.id.

7. Khoirul, A. 2013. Hubungan Pemahaman Penolong Dengan Tindakan Pertolongan Pertama pada Korban Kecelakaan Lalu Lintas di IGD RSUD Ungaran dan IGD RSUD Ambarawa. 
8. Kurniawan, H. 2014. Hubungan Pengetahuan Penanganan Kondisi Gawat Darurat Terhadap Pertolongan Pertama pada Kecelakaan Lalu Lintas.

9. Mubarak, W. I. 2009. Ilmu Keperawatan Komunitas: Konsep dan Aplikasi. Jakarta: Salemba Medika.

10. Muhsin, A. 2017. Hubungan Tingkat Usia Dengan Disiplin Belajar Mahasiswa Madrasah Semester VIII di Universitas Pesantren Tinggi Darul Ulum.

11. Niven, N. 2012. Psikologi Kesehatan Pengantar untuk Perawat dan Profesional Kesehatan. Jakarta: Rineka Cipta.

12. Notoatmodjo, S. 2010. Ilmu Prilaku Kesehatan. Jakarta: Rineka Cipta.

13. Prasetyo, D. D. 2017. Identifikasi Tingkat Pengetahuan Masyarakat Pesisir Tentang Pertolongan Pertama pada Kejadian Tenggelam di Desa Batu Gong Kabupaten Konawe Provinsi Sulawesi Tenggara.

14. Purwanto. 2010. Psikologi Perkembangan. Bandung: Remaja Rosida Karya.

15. Suyami. 2012. Tingkat Pengetahuan Masyarakat Tentang Pertolongan Pertama pada Luka Bakar.

16. Wawan, A dan Dewi, M. 2010. Teori dan Pengukuran Pengetahuan, Sikap dan Perilaku Manusia. Yogyakarta: Nuha Medika.

17. Widyastuti, M. 2017. Gambaran Pengetahuan Masyarakat Pesisir Tentang Pertolongan Korban Tenggelam di Kenjeran Surabaya.

18. Wijaya, IM. S. 2016. Tingkat Pengetahuan Bantuan Hidup Dasar pada Masyarakat di Kecamatan Denpasar Utara.

19. World Health Organization. 2015. Global Status Report on Road Safety. Available: www.bin.go.id. 